\title{
Comparing land use registry and sample based inventory to estimate forest area in Podlaskie, Poland
}

\author{
Marek Jabłoński ${ }^{(1)}$, \\ Kari T Korhonen (2), \\ Piotr Budniak ${ }^{(1)}$, \\ Marcin Mionskowski ${ }^{(1)}$, \\ Grzegorz Zajączkowski ${ }^{(1)}$, \\ Krzysztof Sućko ${ }^{(3)}$
}

\begin{abstract}
The Land and Property Register (LPR) of Poland contains information on land use for the entire country. Additionally, a sample-based National Forest Inventory (NFI) provides statistical data for forest areas and detailed information on numerous forest parameters. However, until 2014 NFI plots were established only on areas classified as forest in the LPR. In this article, we present results of an estimation of forest area by extending the NFI measurements on all theoretical points in a grid, and compare the results with LPR information for one province (the Podlaskie voivodeship). At each point, we assess land use with recent aerial photographs and verify the ambiguous points in the field. Forest area in Poland is increasing due to afforestation and natural expansion of for est. Delays in the updating process of the LPR, and unwillingness of the owners to agree to reclassification of their land, have led to an underestimation of overall forest area. Our results demonstrate that forest area estimates made by the improved NFI are higher than those based upon the LPR. The modified NFI may be an appropriate tool for monitoring forest area changes in Poland.
\end{abstract}

Keywords: Land Cover, Afforestation, Natural Expansion of Trees, Land and Property Register, National Forest Inventory

\section{Introduction}

Forests cover almost 4 billion hectares globally, which corresponds to 31 percent of the world's total land area (Keenan et al. 2015). Reporting about forests and their diversity requires a clearly defined system of indicators at various spatial scales (McElhinny et al. 2005, Motz et al. 2010), based directly on tree attributes or area features (Williams et al. 2001) and collected at regular time intervals. Forest assessment systems still need to be developed, particularly on national and global levels (Puumalainen et al. 2003, Corona et al. 2011, Fattorini 2015).

Forests are generally defined by the type of land use or land cover they include, or as an administrative unit (Lund 2002). The definition of a forest is determined by the main goal of assessment (Mathys et al. 2006, Vidal et al. 2008). Differences between national definitions, and those used by international organisations, result in mismatches between the forest areas reported on a national level and country statistics (Lund 2002). Therefore, harmonisation of inventory systems and applied definitions may constitute a better solution than standardisation of forest data (Vidal et al. 2008, Gschwantner et al. 2009, Tomppo \& Schadauer 2012). However, such processes can be difficult to implement due to high costs, national conditions and varying information requirements (Köhl et al. 2000). Thus, developing appropriate methods for converting national data to that which can be merged into international systems (Ståhl et al. 2012, Tomter et al. 2012) may be the only solution.

In most European countries, basic information about forests that is used for formulation of national forest policies and forest ecosystem monitoring comes from $\mathrm{Na}$ tional Forest Inventories (NFIs - Gschwant-

$\square$ (1) Department of Forest Resources Management, Forest Research Institute, Braci Lesnej 3, 05-090 Raszyn (Poland); (2) Natural Resources Institute Finland, PO Box 68 (Yliopistokatu

6), Fl-80101 Joensuu (Finland); (3) Department of Natural Forests, Forest Research Institute, Park Dyrekcyjny 6, 17-230 Bialowieza (Poland)

@ Marek Jabłoński (m.jablonski@ibles.waw.pl)

Received: Apr 07, 2016 - Accepted: Oct 12, 2016

Citation: Jabłoński M, Korhonen KT, Budniak P, Mionskowski M, Zajączkowski G, Sućko K (2017). Comparing land use registry and sample based inventory to estimate forest area in Podlaskie, Poland. iForest 10: 315-321. - doi: 10.3832/ifor2078-009 [online 2017-02-23]

ner et al. 2009, Gabler et al. 2012, Tomppo \& Schadauer 2012). Lawrence et al. (2010) noted that almost all countries that participated in COST Action E43 ("Harmonisation of National Forest Inventories in Europe: Techniques for Common Reporting") use the percentage of crown cover and minimum forest area as basic parameters for forest definition. In some countries, the minimum tree height and minimum forest width are also used. Of the 27 European countries that took part in this process, only eight use crown cover threshold and minimum area definitions consistent with the Food and Agriculture Organization of the United Nations' reference definition (10\% crown cover and 0.5 ha minimum area - FAO 2004) that is applied within COST Action E43 (Vidal et al. 2008).

NFIs estimate forest area by: (1) assessment of field plots or points; (2) interpretation of plot or point locations (inside or outside the forest) using aerial photographs; or (3) assessment of maps (Lawrence et al. 2010). Because NFI plots are smaller than the minimum area used to define a forest (Gabler et al. 2012), classification of land as forest or non-forest requires additional measurements from the area surrounding sample plots.

The continuum from treeless to fully treed vegetation types (Putz \& Redford 2010), which is manifested in diverse tree cover and composition (Kleinn 2001), complicates the classification of land areas. Gabler et al. (2012) proposed two approaches for classifying NFI sample plots as forest or non-forest: (1) a point decision based on the analysis of surrounding area 
Fig. 1 - The study area (grey polygon), showing the NFI grid scheme.

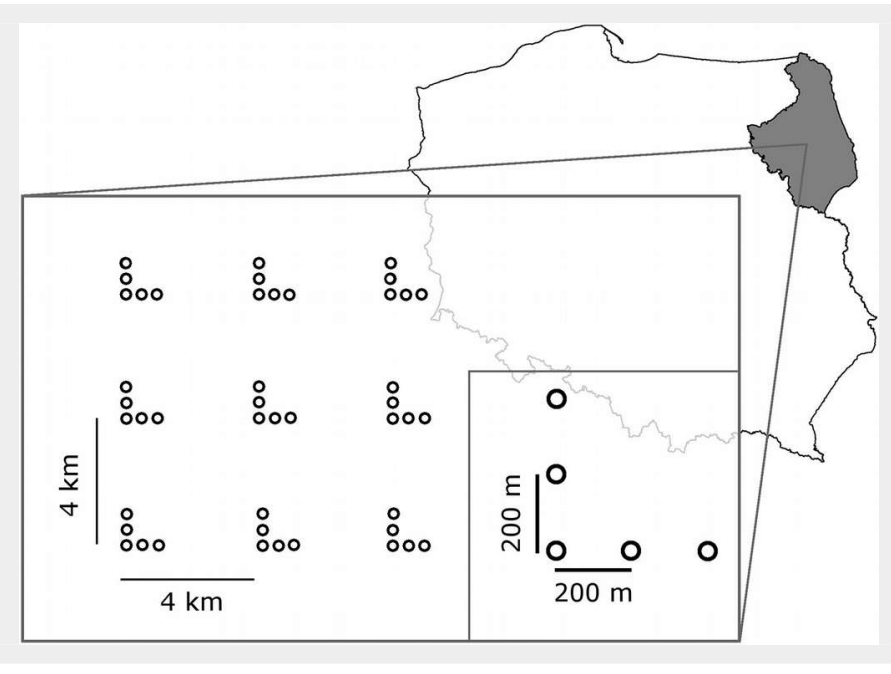

of predefined shape and size; or (2) a point decision based on delineation of the surrounding land into polygons of forest and non-forest land. Using reference areas for crown cover estimation reduces assessment uncertainties (Magdon \& Kleinn 2013). However, Kleinn (2001) noted that the crown cover criterion is only reasonable for open forests (without contact between tree crowns). For closed forests, when a visible demarcation between forest and non-forest exists, a sample point can be defined as outside or inside the forest area (Kleinn 2001).

In 2005, an assessment of forest resources at a national level was initiated in Poland, based on a systematic grid of fixedarea sample plots (Michalak \& Zajaczkowski 2010, Talarczyk 2014). We emphasise that until 2014 the NFI's sample plots were only established in those grid points that were classified as forest in the Land and Property Register (LPR). LPR is a public register, maintained by local government authorities, based on geodetic and cartographic elaborations. The frequency of LPR updating has not been defined. Delays in the reclassification of afforested land, as areas meeting the criteria for forested land monitoring of forest area in Poland.

\section{Materials and methods}

\section{Definition of forests in Poland} area of at least 0.1 ha. Forest land can be well as the natural expansion of trees on abandoned agricultural lands, have led to but not being registered in the LPR as forest. The goal of this paper is to study the usability of LPR for forest area estimation and to propose an improved method for

Polish law defines forest as a land with forest vegetation (with trees, shrubs and herbaceous ground cover) covering an temporarily unstocked as a result of forest management or natural disasters. Lands related to forestry (such as forest roads and nurseries) are also included in the forest area. Elements of forest structure, such as the minimum tree height or canopy cover are not highlighted in this definition; nevertheless, acknowledgement of an area as a forest strictly depends upon its land use classification as defined by the Land and Property Register (Jablonski 2015). Generally, forest land is protected by law, and

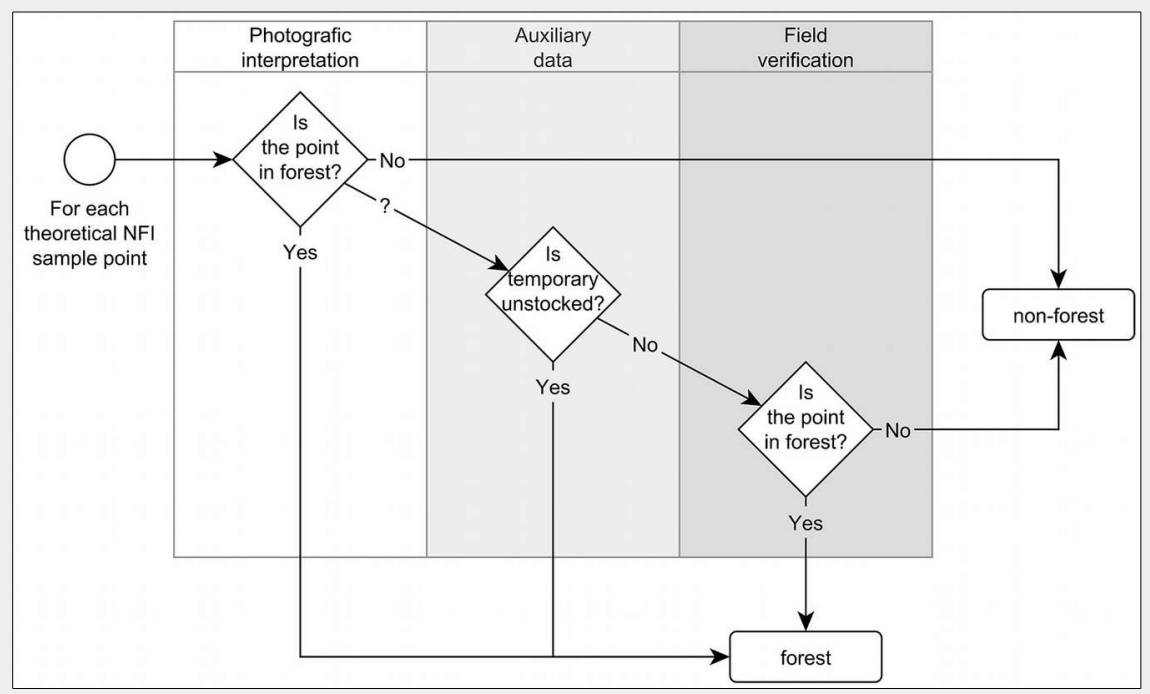

Fig. 2 - Decision tree for classification of NFI points into forest and non-forest classes. deforestation is only allowed with the consent of the Minister of Environment.

Since the Second World War, a vast increase in forest area as a result of afforestation and natural succession has occurred in Poland. Almost 1.5 million hectares of wasteland (unproductive marshy or sandy sites) and agricultural land was afforested between 1945 and 2012 (CSO $2013 \mathrm{~b}$ ). Due to fragmentation of land ownership, very narrow parcels were often planted with trees. In the definition of a forest used for reporting under the United Nations Framework Convention on Climate Change (UNFCCC), a minimum width of 10 $m$ is required for an area to be classified as forest, except in areas with small properties. However, 0.1 hectares has been kept as the minimum area threshold (KOBiZE 2013). Under the UNFCCC, only those forests included in LPR are reported. The minimum width of 20 meters recommended by the FAO (2004) for an area to be classified as forest has only been implemented for afforestation achieved with European Agriculture Guidance and Guarantee Funds (EAGGF). The minimum area for this afforestation ( 0.3 hectares) is also lower than the 0.5 ha FAO threshold.

Reclassification of land from non-forest to forest, particularly that resulting from the natural expansion of trees on abandoned lands, is accomplished using criteria implemented in the State Forests for distinguishing between stocked and unstocked areas. For trees older than 20 years, the stocking index criterion (the growing stock per ha compared to yield table values) is applied. For 21-40 year-old stands, the stocking index cannot be less than 0.4 , whilst for older stands, the index cannot be less than 0.3. For the youngest stands (under 20 years old) the criterion of tree occurrence is used, where there should be at least $50 \%$ trees compared to the planting density. However, afforested areas established with EAGGF funds are reclassified from non-forest to forest land (in LPR) after $4-5$ years if at least $70 \%$ of the planted trees are alive. For natural succession, a threshold of $50 \%$ is used.

\section{Object of the study}

The NFI methodology implemented in Poland uses a $4 \times 4$ kilometre grid with clusters consisting of five plots (Michalak \& Zajaczkowski 2010, Talarczyk 2014). Under this scheme, there are almost 99,000 theoretical sample points in Poland. Out of this number, we analysed the land cover of $6429 \mathrm{NFI}$ points located in northeast Poland (Fig. 1) within the area of the Podlaskie voivodeship (province).

The total area of the Podlaskie voivodeship is 2,018,702 hectares, of which $1,991,100$ is land area (CSO 2013a). According to the Central Statistical Office database, at the end of 2012, forest covered 628,400 hectares of the study area, or $31.1 \%$ of the total area and $31.6 \%$ of the land area of the voivodeship (CSO 2013b). Approxi- 
mately $68 \%$ of the forests within the study area are public and managed by the State Forest Holding. The proportion of private forests $(32.0 \%)$ is higher than average for Poland (18.4\%).

Within the first five-year cycle of the NFI (2005-2009 - NFI I), 1927 sample plots were established in the forest area of the voivodeship. Our study commenced during the second cycle of NFI (NFI II), therefore the total number of plots for $2^{\text {nd }}$ cycle was calculated as the sum of: (1) the measured real data from the first three years of NFI II; and (2) the number of plots planned to be measured during 2013-2014. The second number was assessed in 2012, by examination of land use category in LPR at theoretical NFI points, by the body responsible for NFI field assessment. As the result, 1995 sample points were classified as located on forest land, according to the Polish definition, 68 forest plots from NFI I have now been classified as non-forest, and 136 nonforest points in NFI I are now identified as being in forest, according to the LPR.

\section{Photographic interpretation and field survey}

Analysis of land cover within the study area was conducted in 2012-2013 indepen dently from the Land and Property Register records (Fig. 2). Firstly, the $6429 \mathrm{NFI}$ points in the Podlaskie voivodeship were plotted on an orthophotograph (RGB, 0.25 $\mathrm{m}$ pixel size) maintained by the Geodesy and Cartography Documentation Centre. Source aerial images were taken between 2002 and 2010, but the vast majority of the study area (approximately $85 \%$ ) was covered with images taken in 2006 and later. Some images, especially along the Belarus border, were acquired before 2006 or came from satellite imagery.

Forested areas in Poland are generally closed forests. Thus, it was usually possible to clearly define the location of sample points as inside or outside of forested land. There were only few points located close to the forest borders. In those cases, a decision was made based on position of tree tops or stumps, without field verification. For the sample points located inside the wooded land, the area of small forest patches was estimated using QGIS software. The minimum area threshold of the forest ( 0.1 ha for the national definition and 0.5 ha for the FAO definition) was verified.

Any doubtful points that resulted from unsatisfactory orthophotographic quality or a lack of closed forest character were selected for further examination. These include the areas with possible agricultural land use, such as fruit tree plantations or urban land use.

Assessment of temporarily unstocked areas (resulting from natural disturbances or forest management practises such as clear-cutting) was made using auxiliary data from the NFI and 23 forest divisions located within the Podlaskie voivodeship.
When a doubtful point was located on an area described as temporarily unstocked forest land, it was classified as a forest. Neither remote sensing data, satellite observations, nor aerial photos are sufficient to assess forest cover trends (Van Deusen et al. 2013).

Any doubtful points, not recognised as unstocked forest land, were selected for field assessment, which was performed in the second half of 2012. Some areas that were inaccessible at that time of year (boggy, marshy sites), mainly located in Biebrza National Park, were assessed in 2013.

Classification of sample points as forest or non-forest land during field verification utilised visual evaluation of the crown cover, with thresholds referring to criteria by which to distinguish between stocked and unstocked areas in the State Forest Holding on a minimum area of 0.1 ha (see section "Definition of Forest in Poland"). Although many precise instruments have been developed to measurement crown (canopy) cover (Jennings et al. 1999, Korhonen et al. 2006), they are relatively timeconsuming in practice (Gill et al. 1999, Rautiainen et al. 2005, Fiala et al. 2006, Korhonen et al. 2006). This impracticality makes methods applicable to scientific studies rather unreliable for routine inventories (Rautiainen et al. 2005). For example, measuring crown cover in sample plots using a densiometer (Jennings et al. 1999, Fiala et al. 2006) or Cajanus tube (Rautiainen et al. 2005, Korhonen et al. 2006) is impractical and ineffective in the context of defining large areas as forest and non-forest to aid in decision-making.

\section{Statistical assessment}

Forest area was estimated as a product of the study area and proportion of points located in the forest. The area of the voivodeship is well known from official statistics.

Tab. 1 - Results of NFI points classification based on photographic interpretation and field assessment in relation to NFI I-II.

\begin{tabular}{|c|c|c|c|}
\hline \multicolumn{2}{|c|}{ Forests defined by LPR } & \multirow{2}{*}{$\begin{array}{l}\text { Photographic interpretation } \\
\text { (with support of auxiliary } \\
\text { information) }\end{array}$} & \multirow[b]{2}{*}{ Field assessment } \\
\hline $\begin{array}{l}\text { NFI I } \\
(2005-2009)\end{array}$ & $\begin{array}{l}\text { NFI II } \\
(2010-2014)\end{array}$ & & \\
\hline \multirow[t]{2}{*}{1927 - forest } & $\begin{array}{l}1859 \text { - forest } \\
\text { (remeasured) }\end{array}$ & $\begin{array}{l}1847 \text { - forest } \\
4 \text { - for field verification } \\
8 \text { - non-forest }\end{array}$ & $\begin{array}{l}3 \text { - forest } \\
1 \text { - non-forest }\end{array}$ \\
\hline & $\begin{array}{l}68 \text { - non-forest } \\
\text { (removed) }\end{array}$ & $\begin{array}{l}57 \text { - forest } \\
3 \text { - for field verification } \\
8 \text { - non-forest }\end{array}$ & $\begin{array}{l}2 \text { - forest } \\
1 \text { - non-forest }\end{array}$ \\
\hline \multirow[t]{2}{*}{$\begin{array}{l}4502 \text { - } \\
\text { non-forest }\end{array}$} & $\begin{array}{l}136 \text { - forest } \\
\text { (new plots) }\end{array}$ & $\begin{array}{l}86 \text { - in forest } \\
14 \text { - for field verification } \\
36 \text { - non-forest }\end{array}$ & $\begin{array}{l}12 \text { - forest } \\
2 \text { - non-forest }\end{array}$ \\
\hline & 4366 - non-forest & $\begin{array}{l}76 \text { - forest } \\
109 \text { - for field verification } \\
4181 \text { - non-forest }\end{array}$ & $\begin{array}{l}70 \text { - forest } \\
39 \text { - non-forest }\end{array}$ \\
\hline \multicolumn{2}{|c|}{ Total number of points } & $\begin{array}{l}2066 \text { - forest } \\
130 \text { - for field verification } \\
4233 \text { - non-forest }\end{array}$ & $\begin{array}{l}87 \text { - forest } \\
43 \text { - non-forest }\end{array}$ \\
\hline
\end{tabular}

Proportion of forest was estimated using a binominal distribution approach, as follows (Cochran 1977 - eqn. 1):

$$
\hat{p}=\sum_{i=1}^{n} f_{i} / \sum_{i=1}^{n} m_{i}
$$

where $\hat{p}$ is the estimated proportion of forest, $n$ is the number of clusters, $m_{i}$ is the number of points in cluster $i$ and $f_{i}$ is the number of forest points in cluster $i$.

The standard error of the proportion of forest was estimated to be the square root of the sampling variance, calculated with a formula appropriate for cluster sampling (Cochran 1977, Gabler \& Schadauer 2008 eqn. 2 ):

$$
\hat{v}(\hat{p})=\frac{1}{\left(\sum_{i=1}^{n} m_{i}\right)^{2}} \cdot \frac{n}{n-1} \cdot \sum_{i=1}^{n}\left(f_{i}-\hat{p} \cdot m_{i}\right)^{2}
$$

Using normal approximation (Cochran 1977), 95\% confidence limits for the true proportion of forest $(P)$ were calculated as follows (eqn. 3):

$$
P=\hat{p} \pm[t \sqrt{\hat{v}(\hat{p})}]
$$

where $t$ is the normal deviate corresponding to confidence probability.

\section{Results}

\section{Photographic interpretation}

As a result of the photographic interpretation, 2066 points were classified as forest (according to minimum forest area and canopy cover applied in Poland), 4233 as non-forest, and 130 for field checking (Tab. 1). From the 68 sample plots established during NFI I (2005-2009) and classified as non-forest using LPR during NFI II (20102014), 57 plots were classified as forest based upon land cover assessment in the photographs. Accordingly, from the 136 points classified as non-forest in NFI I and as forest in NFI II using the LPR data, 

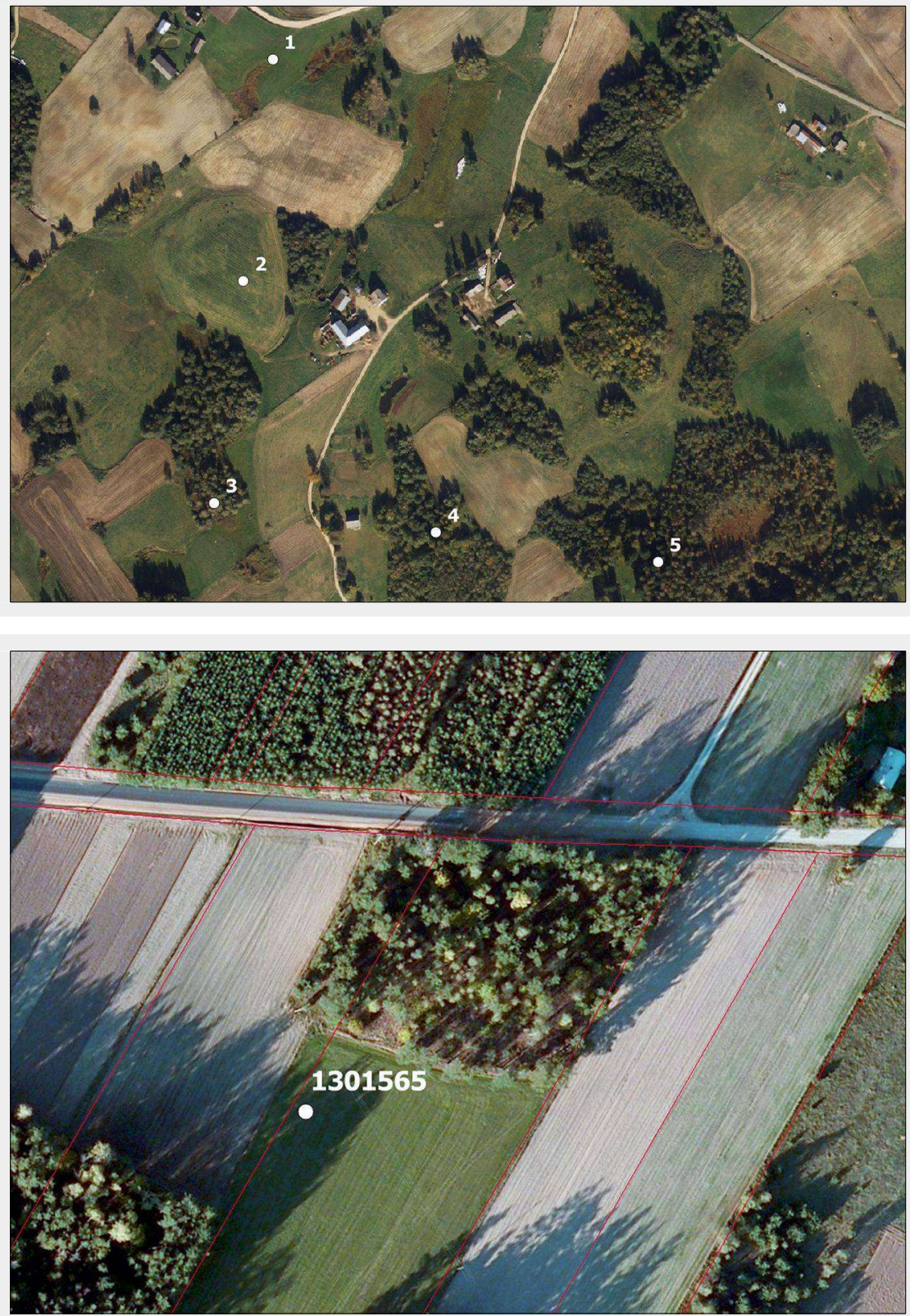

Fig. 3 - NFI's cluster no. 151144. Sample points 3-5 are classified as forest based on photographic interpretation. Only plot 3 belongs to forest land within the LPR and thus it was measured during the NFI II (a 30 year-old silver birch and black alder stand in 2013). Points 4 and 5 are recorded as agricultural land in LPR. In 2008 (NFI I) all of the points were recorded as non-forest in LPR.
Fig. 4 - NFI's sample plot no. 1301565 , located in a parcel described as forest in the LPR. Red lines denote LPR parcel boundaries.
36 points were found to be non-forest and 14 were designated for field verification. Our analysis also revealed 76 points, located on the always non-forest LPR land, with tree cover satisfying the forest definition. Examples of areas classified as forest during photographic interpretation are presented in Fig. 3.

We found that 10 out of 2066 points were placed in patches of forest with an area less than 0.5 hectares, i.e., they are not forests based on the FAO definition.

We should emphasise that some of the points classified as non-forest (14 of 1995 measured in NFI II) are located on areas recorded in LPR as forest. This discrepancy may have been due to the lack of division of land parcels into various land use classes in the LPR, in situations where forest and agricultural or pastoral lands are located in the same land parcel (Fig. 4).

As a result of photographic interpretation, 130 sample points were selected for field verification. According to the LPR, these points are located in: forest areas (18), woodlands (18), pastures (15), wastelands (28), agricultural lands (46), and other areas (5).

\section{Field assessment}

During field assessment, 87 out of the 130 points were classified as forest (Tab. 1). In three cases, the area of these forest patches was lower than 0.5 hectares.

In general, three categories of forest were distinguished on lands classified as non-forest in the LPR, depending upon their origins and current status. The first category includes stands previously classified as woodlands (land with a crown cover or stocking index that does not fulfill the national definition of forest) that have not yet been reclassified as forests in the LPR (Fig. 5). The second category includes naturally afforested stands of birch, alder, pine or spruce, on wastelands and aban- doned agricultural lands (Fig. 6). The last category includes stands resulting from planting, which have not yet been recorded in the LPR. Such stands are usually relatively young (Fig. 7).

Four of the 130 sample points assessed in the field were not recognised as forest, but could be classified as "other land with tree cover" according to the FAO (2004) categories. This definition derives from their use for purposes other than forestry (such as cemeteries and urban or industrial areas).

\section{Statistical assessment}

Based upon photographic interpretation and field assessment, 2153 sample points (33.5\% of the total points from the NFI grid in the study area) were classified as forest.

These numbers correspond to a total forest area of 676,300 ha, which is nearly 48,000 ha more than the official LPR-based estimate. The standard error of estimated 
Fig. 5 - An approximately 70 year-old black alder (Alnus glutinosa L. Gaertn.) stand in Biebrza National Park in an area classified in the LPR as a woodland.

Fig. 6 - An approximately 25 year-old downy birch (Betula pubescens Ehrh.) stand in Biebrza National Park in an area classified in the LPR as a wasteland.

Fig. 7 - An approximately 30 year-old Scots pine (Pinus sylvestris L.) stand that afforested an area classified in the LPR as agricultural land.
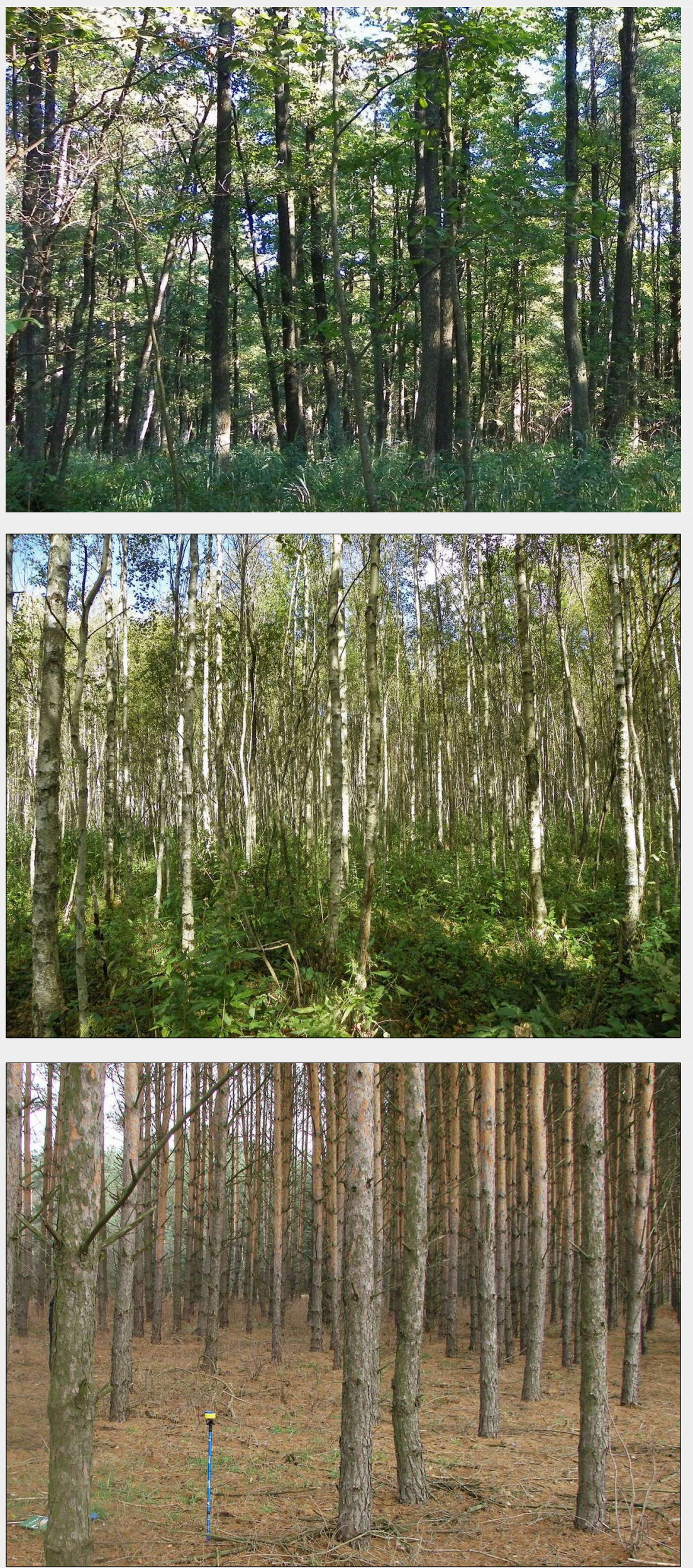
forest percentage using eqn. 2 is $1.1 \%$ (note that the forest proportion was converted to a percentage by multiplying by 100 ). Thus, there is a $95 \%$ probability that the true percentage of forest area is between $31.3 \%$ and $35.7 \%$ ( 631,900 and $720,700 \mathrm{ha}$ ) The lower limit of the confidence interval is still 3500 ha higher than the officially estimated forest area of the voivodeship.

Using the FAO's minimum area for a forest ( 0.5 hectares), 2140 of the NFI points met the definition of a forest. This corre sponds to a forest percentage of $33.3 \% \pm$ $1.1 \%$ (standard error).

\section{Discussion and conclusions}

Forests, similar to other ecosystems, are significantly influenced by human impact (Vitousek et al. 1997). The net change in forest area from 1990-2015 is estimated to have been -5.1 million hectares per year around the world (Keenan et al. 2015). In contrast, the forest area in Europe has been increasing steadily since the 1990s, and the net change is estimated to be 0.8 million hectares per year during the last 25 years (Keenan et al. 2015).

The forest area in Poland increased by approximately 485,000 hectares between 1990 and 2012, but the area of afforestation during this period was only 315,000 hectares (Jablonski 2015). Two main processes likely cause this inconsistency in forest area balance: (1) reclassification of afforestation made before 1990; and (2) natural expansion of forests on abandoned agricultural lands. Our results show that forest area is still underestimated in Poland, because of these reasons.

The percentage of forest land in the Podlaskie voivodeship estimated in our studies (based only on land cover and land use) is approximately 2.4 percentage units higher than official (LPR) data states $(33.5 \%$ and $31.1 \%$, respectively). This difference refers to Polish thresholds of minimum crown cover, applied within our study. Using the FAO criterion for canopy cover, forest area in Poland could be even greater.

Defining a forest as an area with a minimum $10 \%$ canopy cover, as in the FAO (2004) definition, is justified by the significant diversity of forest ecosystems that range from closed to open. Because of ecological zones and natural timberlines, a low threshold is applicable to forests throughout the world (UN-ECE/FAO 2000). Forests in Poland, except for some marshy sites, are closed. For this reason, we chose a higher threshold for crown cover in this study than the FAO proposal. Consequently, some areas in the initial stages of colonising abandoned agricultural land were not included in forest area in our assessment. However, some forest patches (13 points in our study) could not fulfill the minimum area threshold proposed by FAO.

We observed that the accuracy of assessment is highly influenced by the selection of a suitable estimator. Using formulas for simple random sampling (SRS), with the same number of sample points and share of forested area, the standard error of the forest percentage would be almost 50\% less than the error assessed by a cluster sampling estimator (0.6\%) for the study area. Application of SRS formulas for cluster sampling is not advisable, due to the possibility of significant underestimation of the true standard error (Cochran 1977, Stehman 1997).

The spontaneous appearance of trees on abandoned agricultural lands resulting from the decline in traditional agriculture, and accompanying changes in socioeconomic conditions, has been observed all over the world (Tasser et al. 2006, Bowen et al. 2007, Corona et al. 2012). The phenomenon is also observed in Poland, however its extent is unknown (Szwagrzyk 2004). These changes prompt questions regarding the definition of forest and classification of land. Forest land recorded in the Land and Property Register in Poland is protected by law and special permission is required for deforestation, whilst abandoned agricultural land with tree cover can be converted to arable land according to good practice guidelines for agricultural land management. In general, land owners are not interested in removal of trees from abandoned lands, however there is still an unwillingness to reclassify such lands in LPR.

We additionally observed that the problem of defining land as a forest occurs in the case of disasters or specific disturbances. For example, flooding caused by the damming activity of beavers results in conversion of terrestrial habitats to aquatic ones (Nummi \& Kuuluvainen 2013). In our opinion, classification of such areas should be made independently for each case, taking into account the spatial extent and intensity of disturbance.

Results of our study highlight the need for implementing a new system for estimation of forest area in Poland. In most European countries, as well as in China, New Zealand, and the USA, forest areas are assessed within NFIs based upon systematic sampling plots (Lawrence et al. 2010). Furthermore, NFIs are key components of greenhouse gas removal/emission reporting under the UNFCCC and its Kyoto Protocol (Cienciala et al. 2008, Federici et al. 2008, Maniatis \& Mollicone 2010, Corona et al. 2012). Extension of the Polish NFI to assess land cover on all points of the NFI grid is recommended for monitoring forest area changes in Poland, including for UNFCCC purposes.

\section{Acknowledgments}

This work was conducted with funds from the Polish State Forests Holding.

\section{References}

Bowen ME, McAlpine CA, House APN, Smith GC (2007). Regrowth forests on abandoned agricultural land: a review of their habitat values for recovering forest fauna. Biological Conservation 140: 273-296. - doi: 10.1016/j.biocon.20 07.08 .012

Cienciala E, Tomppo E, Snorrason A, Broadmeadow $M$, Colin A, Dunger $K$, Exnerova Z, Lasserre B, Petersson H, Priwitzer T, Sanchez G, Ståhl G (2008). Preparing emission reporting from forests: use of National Forest Inventories in European countries. Silva Fennica 42 (1): $73-$ 88. - doi: 10.14214/sf.265

Corona P, Barbati A, Tomao A, Bertani R, Valentini R, Marchetti M, Fattorini L, Perugini L (2012). Land use inventory as framework for environmental accounting: an application in Italy. iForest 5 (1): 204-209. - doi: 10.3832/ifor 0625-005

Corona P, Chirici G, McRoberts RE, Winter S, Bar bati $A$ (2011). Contribution of large-scale forest inventories to biodiversity assessment and monitoring. Forest Ecology and Management 262: 2061-2069. - doi: 10.1016/j.foreco.2011.08. 044

Cochran WG (1977). Sampling techniques ( $3^{\text {rd }}$ edn). John Wiley and Sons, New York, USA, pp. 448.

CSO (2013a). Environment 2013. Central Statistical Office, Warsaw, Poland, pp. 530. [online] URL: http://stat.gov.pl/files/gfx/portalinformac yjny/pl/defaultaktualnosci/5484/1/14/1/se_ochro na_srodowiska_2013.pdf

CSO (2013b). Forestry 2013. Central Statistical Office, Warsaw, Poland, pp. 319. [online] URL: http://stat.gov.pl/files/gfx/portalinformacyjny/p l/defaultaktualnosci/5510/1/9/5/rl_lesnictwo_201 3.pdf

FAO (2004). Global Forest Resources Assessment Update 2005. Terms and definitions. FAO Forest Resources Assessment Working Paper 83/E. Rome, Italy, pp. 34. [online] URL: http:// www.fao.org/forestry/7797-of7ba44a281b061b 9c964d3633d8bf325.pdf

Fattorini L (2015). Design-based methodological advances to support national forest inventories: a review of recent proposals. iForest 8: 611. - doi: 10.3832/ifor1239-007

Federici S, Vitullo M, Tulipano S, De Lauretis R, Seufert $G$ (2008). An approach to estimate carbon stocks change in forest carbon pools under the UNFCCC: the Italian case. iForest 1: 86-95. doi: 10.3832/iforo457-0010086

Fiala ACS, Garman SL, Gray AN (2006). Comparison of five canopy cover estimation techniques in the western Oregon Cascades. Forest Ecology and Management 232: 188-197. - doi: 10.1016/j.foreco.2006.05.069

Gabler K, Schadauer K (2008). Methods of the Austrian forest inventory 2000/02. Origins, approaches, design, sampling, data models, evaluation and calculation of standard error. BFWBerichte 142, Wien, Austria, pp. 121. [online] URL: http://bfw.dabis.org/!bbfw!2015/04/Inhalt 142.pdf

Gabler K, Schadauer K, Tomppo E, Vidal C, Bonhomme C, McRoberts RE, Gschwantner T (2012). An enquiry on forest areas reported to the global forest resources assessment - is harmonization needed? Forest Science 58 (3): 201213. - doi: 10.5849/forsci.10-060

Gill SJ, Biging GS, Murphy EC (1999). Modeling conifer tree crown radius and estimating canopy cover. Forest Ecology and Management 
126: 405-416. - doi: 10.1016/S0378-1127(99)00113-

Gschwantner T, Schadauer K, Vidal C, Lanz A, Tomppo E, Di Cosmo L, Robert N, Englert Duursma D, Lawrence M (2009). Common tree definitions for National Forest Inventories in Europe. Silva Fennica 43 (2): 303-321. - doi: $10.14214 / \mathrm{sf} .463$

Jablonski M (2015). Definicja lasu w ujeciu krajowym i miedzynarodowym oraz jej znaczenie dla wielkosci i zmian powierzchni lasów w Polsce. [National and international definition of forest and its importance for the forest area in Poland]. Sylwan 159 (6): 469-482. [in Polish] [online] URL: http://sylwan.ibles.waw.pl/pls/ apex/apex_util.get_blob?s=4297718306986225 Jennings SB, Brown ND, Sheil D (1999). Assessing forest canopies and understorey illumination: canopy closure, canopy cover and other measures. Forestry 72: 59-73. - doi: 10.1093/for estry/72.1.59

Keenan RJ, Reams GA, Achard F, De Freitas JV, Grainger A, Lindquist E (2015). Dynamics of global forest area: Results from the FAO Global Forest Resources Assessment 2015. Forest Ecology and Management 352: 9-20. - doi: 10.1016/j. foreco.2015.06.014

Kleinn C (2001). A cautionary note on the minimum crown cover criterion in forest definitions. Canadian Journal of Forest Research 31: 350-356. - doi: 10.1139/x00-154

KOBiZE (2013). Poland's National Inventory Report 2013. Greenhouse Gas Inventory for 19882011. Submission under the UN Framework Convention on Climate Change and its Kyoto Protocol. National Centre for Emission Management (KOBiZE), Warszawa, Poland, pp. 326. [online] URL: http://unfccc.int/files/national re ports/annex_i_ghg_inventories/national_inven tories_submissions/application/zip/pol-2013-nir25may.zip

Korhonen L, Korhonen KT, Rautiainen M, Stenberg $P$ (2006). Estimation of forest canopy cover: a comparison of field measurement techniques. Silva Fennica 40 (4): 577-588. - doi: 10.14214/sf.315

Köhl M, Traub B, Päivinen R (2000). Harmonization and standardization in multi-national environmental statistics - mission impossible? Environmental Monitoring and Assessment 63: 361380. - doi: 10.1023/A:1006257630216

Lawrence M, McRoberts RE, Tomppo E, Gschwantner T, Gabler K (2010). Comparisons of national forest inventories. In: "National Forest Inventories. Pathways for Common Reporting" (Tomppo E, Gschwantner T, Lawrence $\mathrm{M}$, McRoberts RE eds). Springer, New York, USA, pp. 19-32. - doi: 10.1007/978-90-481-3233-1_2

Lund HG (2002). When is a forest not a forest? Journal of Forestry 100 (8): 21-28. [online] URL: http://www.ingentaconnect.com/content/saf/jo f/2002/00000100/00000008/art00007

Magdon P, Kleinn C (2013). Uncertainties of forest area estimates caused by the minimum crown cover criterion - a scale issue relevant to forest cover monitoring. Environmental Monitoring and Assessment 185: 5345-5360. - doi: 10.1007/s10661-012-2950-0

Maniatis D, Mollicone D (2010). Options for sampling and stratification for national forest inventories to implement REDD+ under the UNFCCC. Carbon Balance and Management 5: 9. - doi: 10.1186/1750-0680-5-9

Mathys L, Ginzler C, Zimmermann NE, Brassel P, Wildi $O$ (2006). Sensitivity assessment on continuous landscape variables to classify a discrete forest area. Forest Ecology and Management 229: 111-119. - doi: 10.1016/j.foreco.2006. 03.012

McElhinny C, Gibbons P, Brack C, Bauhus J (2005). Forest and woodland stand structural complexity: its definition and measurement. Forest Ecology and Management 218: 1-24. doi: 10.1016/j.foreco.2005.08.034

Michalak R, Zajaczkowski S (2010). National forest inventory reports - Poland. In: "National Forest Inventories. Pathways for Common Reporting" (Tomppo E, Gschwantner T, Lawrence $M$, McRoberts RE eds). Springer, New York, USA, pp. 425-436.

Motz K, Sterba H, Pommerening A (2010). Sampling measures of tree diversity. Forest Ecology and Management 260: 1985-1996. - doi: 10.1016/ j.foreco.2010.08.046

Nummi P, Kuuluvainen T (2013). Forest disturbance by an ecosystem engineer: beaver in boreal landscapes. Boreal Environment Research (suppl. A): 13-24. [online] URL: http://www.borenv.net/BER/pdfs/ber18/ber18A13.pdf

Putz FE, Redford KH (2010). The importance of defining "forest": tropical forest degradation, deforestation, long-term phase shifts, and further transitions. Biotropica 42 (1): 10-20. - doi: 10.1111/j.1744-7429.2009.00567.x

Puumalainen J, Kennedy P, Folving S (2003). Monitoring forest biodiversity: a European perspective with reference to temperate and boreal forest zone. Journal of Environmental Management 67: 5-14. - doi: 10.1016/S03014797(02)00183-4

Rautiainen M, Stenberg P, Nilson T (2005). Estimating canopy cover in Scots pine stands. Silva Fennica 39 (1): 137-142. - doi: 10.14214/sf.402 Ståhl G, Cienciala E, Chirici G, Lanz A, Vidal C, Winter S, McRoberts RE, Rondeux J, Schadauer K, Tomppo E (2012). Bridging national and reference definitions for harmonizing forest statistics. Forest Science 58 (3): 214-223. - doi: 10.5849/forsci.10-067
Stehman SV (1997). Estimating standard errors of accuracy assessment statistics under cluster sampling. Remote Sensing of Environment 60 (3): 258-269. - doi: 10.1016/So034-4257(96)001 76-9

Szwagrzyk J (2004). Sukcesja lesna na gruntach porolnych; stan obecny, prognozy i watpliwosci [Forest succession on abandoned farmland; current estimates, forecasts and uncertainties]. Sylwan 148 (4): 53-59. [online] URL: http:// sylwan.ibles.waw.pl/pls/apex/apex_util.get_blo $b ? s=4262688178199743$

Talarczyk A (2014). National forest inventory in Poland. Baltic Forestry 20 (2): 333-340. [online] URL: http://www.balticforestry.mi.It/bf/PDF_Ar ticles/201420[2]/NationalforestinventoryinPola nd.pdf

Tasser E, Walde J, Tappeiner U, Teutsch A, Noggler W (2006). Land-use changes and natural reforestation in the Eastern Central Alps. Agriculture, Ecosystems and Environment 118: 115129. - doi: 10.1016/j.agee.2006.05.004

Tomppo EO, Schadauer K (2012). Harmonization of national forest inventories in Europe: advances under COST Action E43. Forest Science 58 (3): 191-200. - doi: 10.5849/forsci.10-091

Tomter SM, Gasparini P, Gschwantner T, Hennig P, Kulbokas $G$, Kuliešis A, Polley $H$, Robert N, Rondeux J, Tabacchi G, Tomppo E (2012). Establishing bridging functions for harmonizing growing stock estimates: examples from European National Forest Inventories. Forest Science 58 (3): 224-235. - doi: 10.5849/forsci.10-068 UN-ECE/FAO (2000). Forest Resources of Europe, CIS, North America, Australia, Japan and New Zealand (industrialized temperate/boreal countries). Geneva Timber and Forest Study Papers No. 17, New York, USA, and Geneva, Switzerland, pp. 445.

Van Deusen PC, Roesch FA, Wigley TB (2013). Estimating forestland area change from inventory data. Journal of Forestry 111 (2): 126-131. doi: 10.5849/jof.12-102

Vidal C, Lanz A, Tomppo E, Schadauer K, Gschwantner T, Di Cosmo L, Robert N (2008). Establishing forest inventory reference definitions for forest and growing stock: a study towards common reporting. Silva Fennica 42 (2): $247^{-}$ 266. - doi: 10.14214/sf.255

Vitousek PM, Mooney HA, Lubchenco J, Melillo JM (1997). Human domination of earth's ecosystems. Science 277: 494-499. - doi: 10.1126/ science.277.5325.494

Williams MS, Schreuder HT, Czaplewski RL (2001). Accuracy and efficiency of area classifications based on tree tally. Canadian Journal of Forest Research 31: 556-560. - doi: 10.1139/xoo193 